\title{
Changes in the nutritive value and aerobic stability of corn silages inoculated with Bacillus subtilis alone or combined with Lactobacillus plantarum
}

\author{
Erika C. Lara ${ }^{\mathrm{A}} \mathrm{B}$, Fernanda C. Basso ${ }^{\mathrm{A}}$, Flávia B. de Assis ${ }^{\mathrm{A}}$, Fernando A. Souza ${ }^{\mathrm{A}}$, \\ Telma T. Berchielli ${ }^{\mathrm{A}}$ and Ricardo A. Reis ${ }^{\mathrm{A}}$ \\ A Department of Animal Science, Sao Paulo State University, Jaboticabal, Sao Paulo, Brazil 14883-900. \\ ${ }^{\mathrm{B} C}$ Corresponding author. Email: erikalarac@gmail.com
}

\begin{abstract}
Chemical composition, fermentation characteristics, in vitro digestibility and aerobic stability were evaluated in corn silage inoculated with microbial additives in two different experiments. Inoculant treatments (untreated, Bacillus subtilis and B. subtilis combined with Lactobacillus plantarum) were applied to fresh forages. Chopped corn plants (2B655 Hx) were ensiled in laboratory silos for periods of 7, 14, 21 and 63 days to evaluate the fermentation parameters. The experimental silos were weighed to determine gas losses. After the ensiling period, the silage was sampled to determine chemical composition and in vitro organic matter digestibility. To evaluate aerobic stability, chopped corn plants (AG-1051) were ensiled in laboratory silos that were opened after 96 days of ensiling. The silage was placed in different buckets containing data loggers. The silage was sampled after $0,4,8$ and 12 days of exposure to air to evaluate the microbial populations and $\mathrm{pH}$. The data were analysed as a completely randomised design using a mixed repeated-measures model in the MIXED procedure of SAS. To evaluate each treatment relative to the fermentation times, a regression analysis using the PROC REG procedure of SAS was applied. A significance level of $P<0.05$ was used. Inoculation with both strains increased lactic acid concentration, whereas the use of $B$. subtilis alone or combined with L. plantarum improved in vitro apparent organic matter digestibility. In the B. subtilis and B. subtilis combined with L. plantarum silages, moulds and yeasts decreased, and aerobic stability was improved. Inoculation with $B$. subtilis alone or combined with L. plantarum improved the nutritional value and aerobic stability of corn silage.
\end{abstract}

Additional keywords: aerobic deterioration, bacterial inoculant, chemical composition, lactic acid bacteria.

Received 11 July 2014, accepted 11 June 2015, published online 3 August 2015

\section{Introduction}

Corn silage is the most widely used forage in ruminant feed due to its high nutritional value. According to Jobim et al. (2001), the higher the quality of silage, the more oxidation is observed in postopening due to higher levels of residual soluble carbohydrates and lactic acid.

The use of a combination of homofermentative and heterofermentative inoculants has become common practice for obtaining silage of improved nutritional value that is also less susceptible to deterioration under aerobic conditions. These inoculants are composed of facultative heterofermentative bacteria (for example, Lactobacillus plantarum) and obligatory heterofermentative bacteria (for example, Lactobacillus buchneri).

The use of microbiological additives has been recommended to overcome the problem of aerobic spoilage of silage under aerobic conditions, and the suggested types of inoculants include Bacillus subtilis (Phillip and Fellner 1992; Basso et al. 2012). Many species and strains of Bacillus produce various antimicrobial substances. These substances include antibiotics that can be used in the biological control of phytopathogens (Lanna Filho et al. 2010).

However, Bacillus species also produce other compounds, such as lactic acid and acetic acid. Although the growth of such bacteria is not suppressed by these fermentation products or by low $\mathrm{pH}$, these organisms are generally less efficient than lactic acid bacteria (L. plantarum) at producing lactic acid (Pahlow et al. 2003). Thus, combining Bacillus with lactic acid bacteria (L. plantarum) may be an alternative for decreasing fermentation losses and protein degradation through a greater production of lactate and additionally enhancing the aerobic stability of silages (Phillip and Fellner 1992).

Several studies have shown that both types of inoculant can improve the efficiency of fermentation and the nutritive value of silages and haylages (McAllister et al. 1995; Muck 2004; Zahiroddini et al. 2004), but these responses are not consistent (Kung et al. 2003; Muck 2004; Baah et al. 2011).

Nevertheless, no previous studies have examined the effects of the inoculation of corn silage with B. subtilis on 
silage fermentation and chemical composition and in vitro dry matter (DM) and organic matter (OM) digestibility. The aim of this study is to evaluate the effects of B. subtilis alone and in combination with $L$. plantarum on the fermentation, nutritive value and aerobic stability of corn silage.

\section{Materials and methods}

Experiment 1: fermentative profile and nutritive value of corn silage

The trial was conducted at Sao Paulo State University - UNESP (Jaboticabal, Sao Paulo, Brazil), located at $21^{\circ} 14^{\prime} 14.04^{\prime \prime} \mathrm{S}$ and $48^{\circ} 17^{\prime} 27.92^{\prime \prime} \mathrm{W}$.

A 2B655 Hx corn hybrid (Dow Agrosciences, Guaíra, SP, Brazil) was sown on 10 January 2009, and harvested on 21 April 2009. The corn plants were harvested manually, using a machete, at a height of $20 \mathrm{~cm}$ above the soil. The forage was chopped to achieve a theoretical length of cut of $10 \mathrm{~mm}$ in a stationary machine (Penha, Ribeirao Preto, SP, Brazil).

The following treatments were applied to the fresh forage: untreated (Control), B. subtilis (BS $\left.-1 \times 10^{5} \mathrm{cfu} / \mathrm{g}\right)$ and the combination of BS and L. plantarum (BSLP). The combination of microorganisms was applied to fresh forage at a rate of $1 \times 10^{5} \mathrm{cfu} / \mathrm{g}$ for each inoculant.

The application rate of the inoculants was determined in accordance with Basso et al. (2012) for tropical conditions. The correct amount of inoculants for each treatment was weighed to achieve the desired application rates. The inoculants were diluted in distilled water to achieve a ratio of $5 \mathrm{~mL} / \mathrm{kg}$ of fresh forage and then applied in a uniform manner with a spray to the fresh forage with constant mixing. The Control silage received a similar amount of distilled water.

Immediately after inoculation, samples of fresh forage from all treatments were obtained to determine DM, ash, crude protein (CP), neutral detergent fibre (NDF), ammonia- $\mathrm{N}$ content relative to total nitrogen content $\left(\mathrm{NH}_{3} / \mathrm{TN}\right)$ and $\mathrm{pH}$ values.

Chopped forage from each treatment was packed into minisilos (2.5 L; anaerobic jars) in triplicate, sealed with a lid and stored at room temperature (average $25^{\circ} \mathrm{C}$ ). The mini-silos remained closed for 7, 14, 21 and 63 days.

The mini-silos were weighed after filling and at the end of each fermentation period to determine the gas losses by subtracting the final weights from the initial weights of the mini-silos and then dividing this difference by the dry weight of the ensiled material (Jobim et al. 2007).

After each fermentation period, the mini-silos were opened, and the silage was homogenised and sampled to determine the DM content, $\mathrm{pH}$ values, $\mathrm{NH}_{3} / \mathrm{TN}$ and the concentrations of lactic and acetic acid, as well as ash, OM, CP, NDF, and in vitro apparent OM digestibility (IVDOM).

The samples to be used to determine the fermentation characteristics ( $\mathrm{pH}$ value, $\mathrm{NH}_{3} / \mathrm{TN}$, and concentrations of lactic and acetic acids) were stored at $-20^{\circ} \mathrm{C}$ for the subsequent preparation of an aqueous extract. Samples to be used to determine the chemical composition were stored in dried form.

An aqueous extract was prepared from the wet samples of silage according to Kung et al. (1984). The $\mathrm{pH}$ was determined using a pH meter (MA522 model, Marconi Laboratory Equipment,
Piracicaba, SP, Brazil). The acetic acid was measured using a Shimadzu GC2014 (SHIMADZU Corporation, Kyoto, Japan) gas chromatograph with an HP-INNOwax capillary column $(30 \mathrm{~m} \times 0.32 \mathrm{~mm}$; Agilent Technologies, Colorado Springs, CO, USA) at an initial temperature of $80^{\circ} \mathrm{C}$ and a final temperature of $240^{\circ} \mathrm{C}$. Lactic acid was determined by a colourimetric method (Barker and Summerson 1941). Ammonia-N (\%TN) was measured by distillation (AOAC 1996; 941.04).

Samples were oven-dried $\left(55^{\circ} \mathrm{C}\right.$ for $\left.72 \mathrm{~h}\right)$ and processed in a knife mill to pass through $1-\mathrm{mm}$ screen sieves and then analysed for DM $\left(105^{\circ} \mathrm{C}\right.$ for $\left.12 \mathrm{~h}\right)$ and ash $\left(500^{\circ} \mathrm{C}\right.$ for $\left.5 \mathrm{~h}\right)$. The OM was calculated. The NDF was analysed using a neutral detergent solution and heat-stable $\alpha$-amylase without sodium sulfite according to Mertens (2002) and determined in an autoclave at $110^{\circ} \mathrm{C}$ for $40 \mathrm{~min}$ (Senger et al. 2008). TN was determined by the Kjeldahl method (AOAC 1996; - ID 954.01), and $\mathrm{CP}$ was calculated as $\mathrm{TN} \times 6.25$.

The IVDOM was estimated from gas production according to Menke et al. (1979) and Mauricio et al. (1999). Samples (200 mg) were incubated in serum bottles (115 mL) (Mauricio et al. 1999) with an addition of $30 \mathrm{~mL}$ of buffered rumen fluid (Menke et al. 1979) in a water bath at $39^{\circ} \mathrm{C}$. Accumulated head-space gas pressure measurements were performed using a needle attached to a pressure transducer connected to a visual display (Datalogger pressure - pressDATA 800, MPL, Piracicaba, SP, Brazil). Readings were taken at regular intervals throughout the incubation period and at an increased frequency during the initial lag and rapid fermentation phases (for example, 2, 4, 6, $8,10,12,24,48$ and $72 \mathrm{~h}$ post-inoculation). Bottles containing buffered rumen fluid without samples were used as blanks. However, the blank correction was omitted because, according to Cone et al. (1997), microbial turnover in the blank begins after $1 \mathrm{~h}$ and $\sim 30 \%$ of the maximum blank reading can be attributed to this turnover in the presence of substrate. As a result, the blank does not accurately reflect what occurs in the sample.

The IVDOM was estimated [Eqn (1)] as follows (Menke et al. 1979):

$$
\begin{aligned}
\operatorname{IVDOM}(\%)= & 14.88+[(0.889 * \operatorname{gas} 24) \\
& \left.+\left(0.045^{*} \mathrm{CP}\right)+\left(0.065^{*} \text { ash }\right)\right],
\end{aligned}
$$

where gas 24 is the gas production in $24 \mathrm{~h}(\mathrm{~mL} / 0.2 \mathrm{~g} \mathrm{DM})$ and the content of CP and ash is expressed in $\mathrm{g} / \mathrm{kg} \mathrm{DM}$.

The rumen fluid was collected from two ruminally cannulated beef steers in the morning before feeding. The fluid was filtered through two layers of cheesecloth into pre-warmed thermos flasks, homogenised and mixed with buffering solution. The steers were fed $60 \%$ of corn silage without inoculant and $40 \%$ of concentrate on a DM basis.

The experiment was performed with a completely randomised design with three replicates. The data were analysed with a mixed model with repeated-measures using the MIXED procedure of SAS (version 9.0 SAS Institute Inc., Cary, NC, USA). The best covariance structure was chosen based on the minimum Akaike information criterion. Differences between means at each time were determined using the DIFF procedure, which differentiates means based on a Fisher's $F$-protected least significant difference test. To evaluate each treatment according to the ensilage times, 
a regression analysis was applied using the PROC REG procedure of SAS. A significance level of $P<0.05$ was used.

\section{Experiment 2: aerobic stability and occurrence of microorganisms in inoculated corn silage}

The corn hybrid used was AG-1051 (Monsanto, Barretos, SP, Brazil). The crop was manually cut at a height of $20 \mathrm{~cm}$ from the soil and chopped to achieve a theoretical length of $10 \mathrm{~mm}$ in a stationary machine (Penha).

The treatments and application rate were the same as those used in Experiment 1 (Control, BS and BSLP). Four mini-silos were used per treatment. The mini-silos remained closed for 96 days.

Immediately after inoculation, samples of fresh forage from all treatments were obtained to characterise the corn plants, as in the previous experiment. Butyric and propionic acids were determined like acetic acid. After mini-silos opening, all spoiled silage was removed, and samples were collected as previously described to evaluate nutritive value as well as yeast and moulds counts and in vitro DM and OM digestibility.

For microbiological analyses, $25 \mathrm{~g}$ of either the fresh forage or silage sample from each replicate were homogenised in $225 \mathrm{~mL}$ of peptone sterile water $(1 \mathrm{mg} / \mathrm{mL})$. The yeast and mould counts were performed on a spread-plate of potato dextrose agar acidified with lactic acid (85\%) according to Cherney and Cherney (2003), and the plates were grown at $28^{\circ} \mathrm{C}$ for 3 and 5 days, respectively. All the microbiological data were $\log$ transformed.

In addition, the silage was subjected to an aerobic stability test. Approximately $3 \mathrm{~kg}$ of silage from each mini-silo was placed in plastic buckets and kept at room temperature (average on $26^{\circ} \mathrm{C}$ ). The temperature of the silage was measured every half hour for 12 days with a data logger placed in the silage during aerobic exposure. The room temperature was measured with a data logger placed near the mini-silos. The aerobic stability of the silage was defined as the number of hours for which the temperature of the silage remained stable before increasing more than on $2^{\circ} \mathrm{C}$ above room temperature. Moreover, we evaluated the $\mathrm{pH}$ values and the yeast and mould counts ( $0,4,8$ and 12 days), as described previously.

The data were analysed using a completely randomised design with four replicates and with a mixed model using the MIXED procedure of SAS (version 9.0 SAS Institute Inc.). The data for aerobic exposure were analysed using the MIXED procedure of SAS with repeated-measures. Unstructured and Toeplitz were the best covariance structures chosen according to the minimum Akaike information criterion. Differences between the means were determined using the DIFF procedure, which differentiates means based on a Fisher's $F$-protected least significant difference test. A significance level of $P \leq 0.05$ was used.

\section{Results}

Experiment 1: fermentative profile and nutritive value of corn silage

Silage inoculated with BSLP had a lower DM content than the Control and BS silages up to 21 days after ensilage $(P<0.05$; Fig. 1). On the 63rd day after ensilage, the DM content was similar among the silages; however, the decrease from the whole-corn plants to the silage was higher in the Control and BS silages than in the BSLP silage (Fig. 1).

All silages had similar values of lactic acid content up to the 7 th day after ensilage, but the BSLP silage had a higher lactic acid content than the others after the 14th and 21st days $(P<0.05$; Fig. 1). On the 63rd day after ensilage, the lactic acid content of the BS silage was lower than that of the other treatments. The Control and BSLP silages showed increases in lactic acid over time; however, the lactic acid content of the BS silage remained stable (Fig. 1).

Up to the 7th and 14th days after ensilage, the acetic acid concentration was higher in the Control silage than in the BS and BSLP silages $(P<0.05)$, but it decreased after the 21 st and 63rd day. The Control and BS silages had a lower acetic acid content than the BSLP silage on the 63rd day after ensilage $(P<0.05$; Fig. 1$)$. The acetic acid concentrations of all silages decreased from the 7 th to the 63rd day (Fig. 1).

All silages had $\mathrm{pH}$ values below 4 on the 7 th day after ensilage $(P<0.05$, Fig. 1$)$ and remained stable until 63 days after ensilage; however, the BSLP silage had higher $\mathrm{pH}$ values than the other silages over time $(P<0.05$, Fig. 1$)$.

The ammonia- $\mathrm{N}(\% \mathrm{TN})$ content was similar among the silages throughout the time of ensilage $(P>0.05)$. The ammonia-N (\%TN) content increased from the ensiling day to the 7th day after ensilage and remained high until 63 days after ensilage.

Gas losses were higher in the BSLP silage than in the Control and BS silages on the 7th and 63rd days after ensilage $(P<0.05)$. The gas losses of all silages increased from the 7 th to the 63rd day (Fig. 1).

The OM content of the silages was similar up to the 14th day after ensilage. After the 21st and 63th days of ensilage, the BSLP silage had a lower OM content $(P<0.01$, Fig. 2$)$. All silages had a greater OM content than the whole-corn plants (evaluated at Day 0) up to the 7th day after ensilage (Fig. 2).

The CP content of the silages was similar up to the 7th day after ensilage. From the 14th day after ensilage, the Control silage had a lower CP content than the BS and BSLP silages $(P<0.05$, Fig. 2). The CP content of all silages (evaluated at Day 7) was lower than the whole-corn plants (Day 0).

The NDF content was lower in the BS and BSLP than in the whole-corn plants immediately after the inoculation of microorganisms on the day of ensilage $(P<0.05$, Fig. 2$)$. The NDF content of the silages (Days 7, 21 and 63) was lower than that of the whole-corn plants. During the days following ensilage, the NDF content was lower in both of the inoculated silages.

The IVDOM values were greater in the inoculated silages than in the Control during the days following ensilage $(P<0.05$, Fig. 2).

\section{Experiment 2: aerobic stability and occurrence of microorganisms in inoculated corn silage}

The inoculated silages showed a higher concentration of lactic acid than did the Control (Table 1). The silage inoculated with BS alone had the highest concentrations of acetic acid and butyric acid, followed by the silage inoculated with BSLP. The highest lactic: acetic acid ratio was observed in the Control and BS 

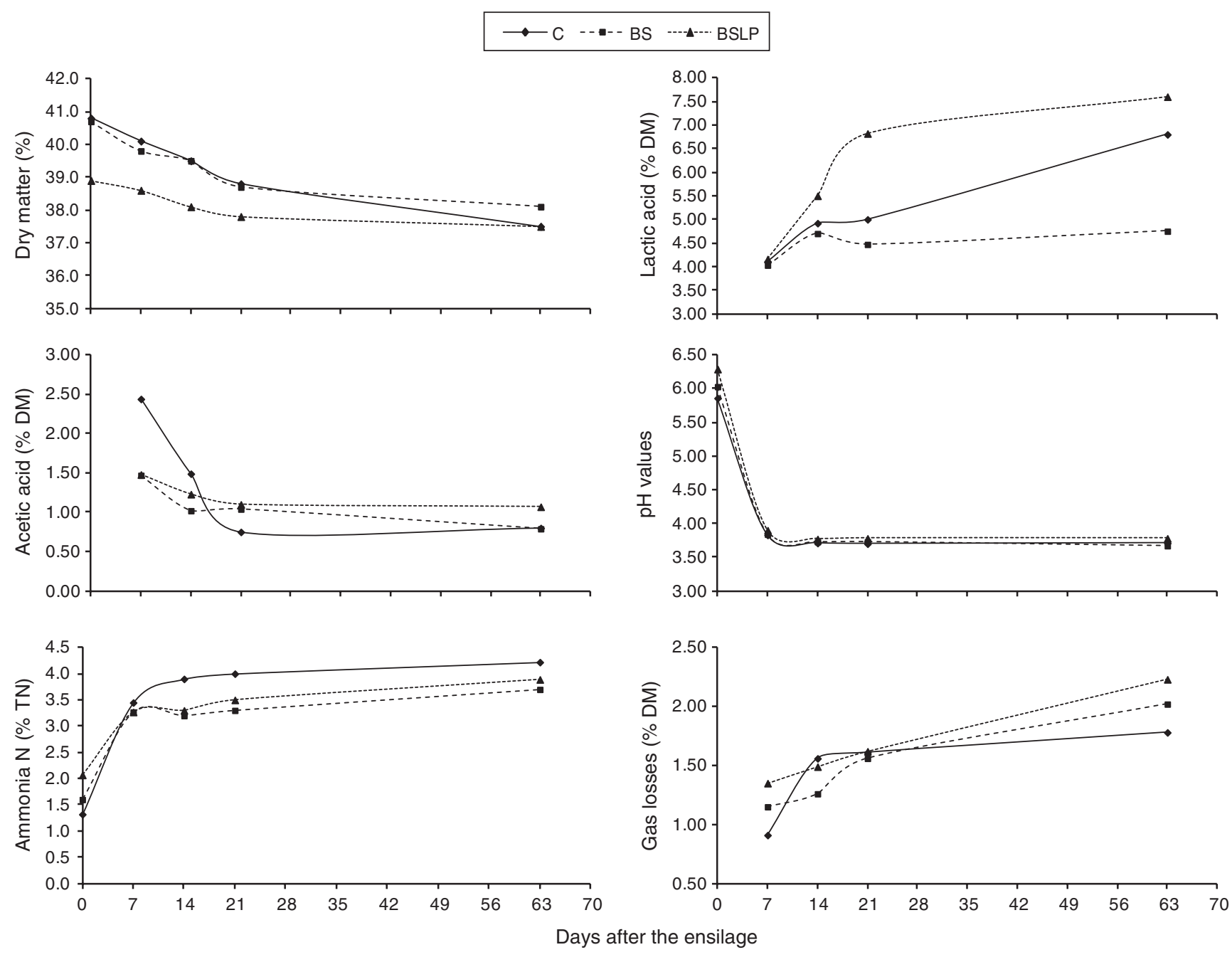

Fig. 1. Changes in fermentation after ensilage. Silages: C, Control; BS, Bacillus subtilis; BSLP, Bacillus subtilis and Lactobacillus plantarum.

silages. Propionic acid was not detected in any of the silages (Table 1).

The DM and ash concentrations were similar among the silages (Table 1). The $\mathrm{CP}$ and ether extract concentrations were greater in the BS and BSLP silages than in the Control silage. However, the concentrations of NDF, hemicellulose and lignin were lower in the inoculated silages (Table 1). The acid detergent fibre and cellulose concentration were lowest in the BSLP silage. Silage inoculation improved in vitro DM and OM digestibility relative to the corresponding values for the Control silage (Table 1).

All silages showed lower $\mathrm{pH}$ values at the opening of the mini-silos compared with the other days (Table 2). After 4 days of aerobic exposure, the silage inoculated with BS alone had a lower $\mathrm{pH}$ value than the other silages. The occurrence of yeasts and moulds showed a significant interaction between silages and days of aerobic exposure $(P<0.0001)$. The occurrence of yeasts was lowest in the BS silage on the day when the minisilos were opened (Day 0). Both inoculated silages had lower yeast concentrations after the 4th and 8th days of aerobic exposure. After 4 days of exposure to the air, the occurrence of moulds was lowest in the BS silage (Table 2).

The silage inoculated with BS had the highest aerobic stability, followed by the BSLP silage (Figs 3 and 4). The BS and BSLP silages were stable for 79 and $54 \mathrm{~h}$, respectively, whereas the Control silage was stable for $23 \mathrm{~h}$.

\section{Discussion}

The DM content of whole-crop corn at the time of ensiling (mean of $40 \%$ ) was above the minimum value of $25 \%$ proposed by McDonald et al. (1991) as that necessary to lower nutrient losses and maintain forage ensiled under suitable conditions.

Increases in lactic acid content during the days following ensilage were observed in the silage that received the two inoculants in combination. This result is expected for silage that receives LP bacteria (Kung 2009). The silage inoculated with BS alone had a lower content of lactic acid because this compound is not the principal end-product of this fermentation pathway. 


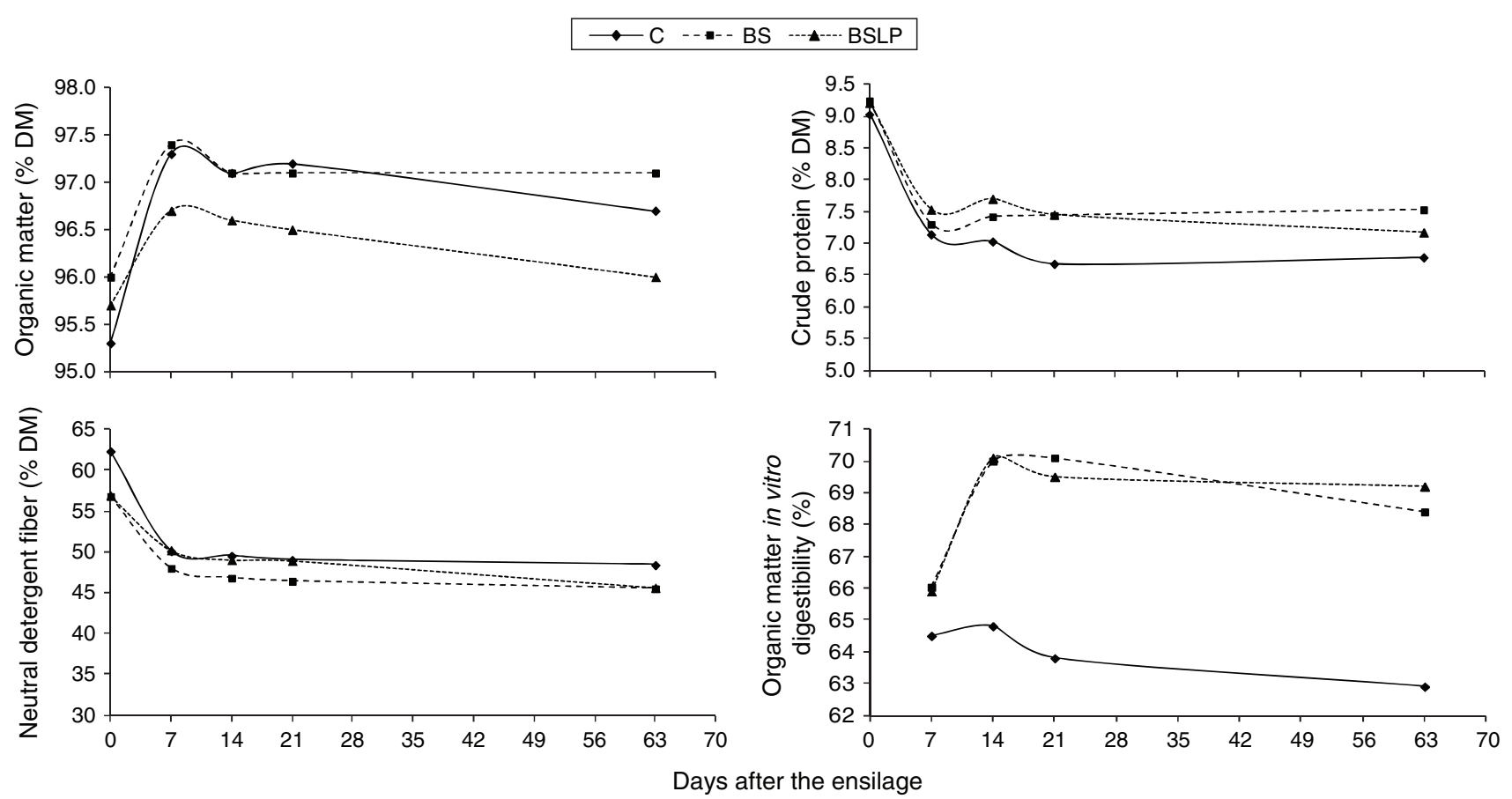

Fig. 2. Changes in chemical composition after ensilage. Silages: C, Control; BS, Bacillus subtilis; BSLP, Bacillus subtilis and Lactobacillus plantarum.

Table 1. Fermentation profile, chemical composition and apparent digestibility of corn silages inoculated with microbial inoculants Silages: Control $=$ untreated. $\mathrm{BS}=$ Bacillus subtilis at $1 \times 10^{5} \mathrm{cfu} / \mathrm{g}$ of fresh forage. $\mathrm{BSLP}=$ B. subtilis and L. plantarum at $1 \times 10^{5} \mathrm{cfu} / \mathrm{g}$ of fresh forage. Means followed by different letters in a row differ to $5 \%$ of significance. These values do not include a comparison with the unensiled crop

\begin{tabular}{|c|c|c|c|c|c|c|}
\hline Item & Forage & Control & $\mathrm{BS}$ & BSLP & s.e.m. & $P$-value \\
\hline \multicolumn{7}{|c|}{ Fermentation characteristics $(\mathrm{g} / \mathrm{kg})$ of dry matter } \\
\hline Lactic acid & - & $47 \mathrm{~b}$ & $53 \mathrm{ab}$ & $60 \mathrm{a}$ & 2.30 & 0.044 \\
\hline Acetic acid & - & $9.0 \mathrm{c}$ & $17 \mathrm{a}$ & $13 b$ & 0.94 & 0.001 \\
\hline Butyric acid & - & $0.5 \mathrm{c}$ & $1.5 \mathrm{a}$ & $1.2 \mathrm{~b}$ & 0.01 & 0.001 \\
\hline Lactic: acetic ratio & - & $5.0 \mathrm{a}$ & $3.0 \mathrm{~b}$ & $5.0 \mathrm{a}$ & 0.22 & 0.001 \\
\hline $\mathrm{pH}$ & 6.02 & $3.81 \mathrm{~b}$ & $3.85 \mathrm{a}$ & $3.84 \mathrm{a}$ & 0.01 & 0.017 \\
\hline Ammonia-N (g/kg of total $\mathrm{N})$ & 2.15 & 4.68 & 4.58 & 4.73 & 0.08 & 0.799 \\
\hline \multicolumn{7}{|c|}{ Chemical composition ( $\mathrm{g} / \mathrm{kg}$ of dry matter) } \\
\hline Dry matter & 354 & 355 & 343 & 351 & 2.13 & 0.058 \\
\hline Ash & 38 & 32 & 30 & 31 & 1.03 & 0.729 \\
\hline Crude protein & 103 & $83 c$ & $92 \mathrm{a}$ & $89 \mathrm{~b}$ & 1.29 & 0.001 \\
\hline Ether extract & - & $22 b$ & $28 \mathrm{a}$ & $32 \mathrm{a}$ & 1.55 & 0.076 \\
\hline Neutral detergent fibre & 514 & $499 a$ & $435 b$ & $393 c$ & 13.55 & 0.001 \\
\hline Acid detergent fibre & 314 & $261 \mathrm{a}$ & $247 \mathrm{ab}$ & $226 b$ & 5.60 & 0.014 \\
\hline Hemicellulose & 200 & $238 \mathrm{a}$ & $188 \mathrm{~b}$ & $167 \mathrm{c}$ & 9.01 & 0.001 \\
\hline Cellulose & - & $207 \mathrm{a}$ & $199 \mathrm{ab}$ & $192 b$ & 2.99 & 0.001 \\
\hline Lignin & - & $41 \mathrm{a}$ & $29 b$ & $27 \mathrm{~b}$ & 2.05 & 0.003 \\
\hline \multicolumn{7}{|c|}{ In vitro apparent dry matter and organic matter digestibility $(\mathrm{g} / \mathrm{kg})$} \\
\hline Dry matter & - & $560 \mathrm{~b}$ & $682 \mathrm{a}$ & $693 a$ & 18.35 & 0.001 \\
\hline Organic matter & - & $659 b$ & $713 \mathrm{a}$ & $710 \mathrm{a}$ & 8.29 & 0.001 \\
\hline
\end{tabular}

Facultative heterofermentative inoculants produce lactic acid as the main fermentation product and can yield an improvement of $1-2 \%$ in DM recovery (Weinberg and Muck 1996). However, the gas losses were unexpectedly greater in the silage containing both inoculants (BSLP).
The decrease in the $\mathrm{CP}$ content and increase in the $\mathrm{NH}_{3} / \mathrm{TN}$ ratio up to the Day 7 of fermentation occurred due to the action of proteases, which are released into the medium due to rupturing plant cell walls (McDonald et al. 1991). After the lowering of the $\mathrm{pH}(<4)$, these plant enzymes become inactive, 
Table 2. Occurrence of spoilage microorganisms in the corn silages inoculated with microbial inoculants during aerobic exposure

Silages: Control $=$ untreated. $\mathrm{BS}=$ Bacillus subtilis at $1 \times 10^{5} \mathrm{cfu} / \mathrm{g}$ of fresh forage. $\mathrm{BSLP}=$ B. subtilis and L. plantarum at $1 \times 10^{5} \mathrm{cfu} / \mathrm{g}$ of fresh forage. Means followed by different uppercase letters in the same column or different lowercase letters in the same row differ (Tukey test, $P \leq 0.05$ )

\begin{tabular}{lccl}
\hline Aerobic exposure & \multicolumn{1}{c}{ Control } & \multicolumn{1}{c}{ BS } & BSLP \\
\hline \multicolumn{4}{c}{ Yeasts $\left(\log _{10}\right.$ cfu/g of silage) } \\
0 & $4,0 \mathrm{aC}$ & $1.6 \mathrm{bC}$ & $3.5 \mathrm{aC}$ \\
4 & $8.9 \mathrm{aA}$ & $7.8 \mathrm{bB}$ & $8.0 \mathrm{bAB}$ \\
8 & $9.3 \mathrm{aA}$ & $8.5 \mathrm{bA}$ & $8.5 \mathrm{bA}$ \\
12 & $8.2 \mathrm{~B}$ & $8.1 \mathrm{~B}$ & $7.9 \mathrm{~B}$ \\
& Moulds $\left(\log _{10}\right.$ cfu/g of silage) & \\
0 & $3.9 \mathrm{C}$ & $4.0 \mathrm{C}$ & $4.2 \mathrm{C}$ \\
4 & $6.6 \mathrm{aB}$ & $4.0 \mathrm{bBC}$ & $6.5 \mathrm{aB}$ \\
8 & $7.1 \mathrm{AB}$ & $7.3 \mathrm{~A}$ & $7.5 \mathrm{~A}$ \\
12 & $7.5 \mathrm{~A}$ & $7.5 \mathrm{~A}$ & $7.6 \mathrm{~A}$ \\
& & & \\
0 & $3.81 \mathrm{C}$ & $3.84 \mathrm{D}$ & $3.83 \mathrm{aD}$ \\
4 & $4.74 \mathrm{aB}$ & $4.35 \mathrm{bC}$ & $4.65 \mathrm{aC}$ \\
8 & $4.67 \mathrm{~B}$ & $4.85 \mathrm{~B}$ & $4.91 \mathrm{aB}$ \\
12 & $6.11 \mathrm{aA}$ & $6.36 \mathrm{aA}$ & $5.49 \mathrm{bA}$ \\
\hline
\end{tabular}

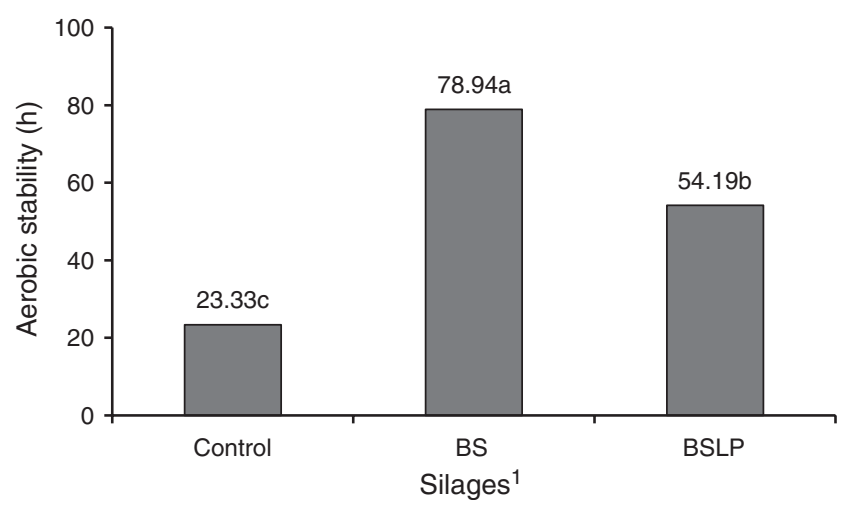

Fig. 3. Aerobic stability of corn silages inoculated with microbial inoculants during aerobic exposure. Silages: Control $=$ untreated. $\mathrm{BS}=$ Bacillus subtilis at $1 \times 10^{5} \mathrm{cfu} / \mathrm{g}$ of fresh forage. BSLP $=B$. subtilis and Lactobacillus plantarum at $1 \times 10^{5} \mathrm{cfu} / \mathrm{g}$ of fresh forage.

resulting in stable values of $\mathrm{CP}$ and $\mathrm{NH}_{3} / \mathrm{TN}$ after the 7th day of fermentation (Muck 1996).

The decrease in the NDF content observed after ensiling may be due to the action of hemicellulases from the plant and the action of acid hydrolysis to solubilise the hemicellulose, a natural process that occurs during ensilage (Pahlow et al. 2003). Additionally, silages inoculated with BS alone or associated with LP had lower concentrations of NDF. The finding of this study that the lowest NDF content was found in silage inoculated with BS is consistent with the results reported by Basso et al. (2011), who noted a decrease in the NDF and hemicellulose concentrations in silages inoculated with BS alone or associated with LP relative to the Control (silage without inoculant).

Silage inoculants were also responsible for the improved in vitro $\mathrm{DM}$ and $\mathrm{OM}$ digestibility. This result implies that the decrease in the NDF content contributed to the improvement in

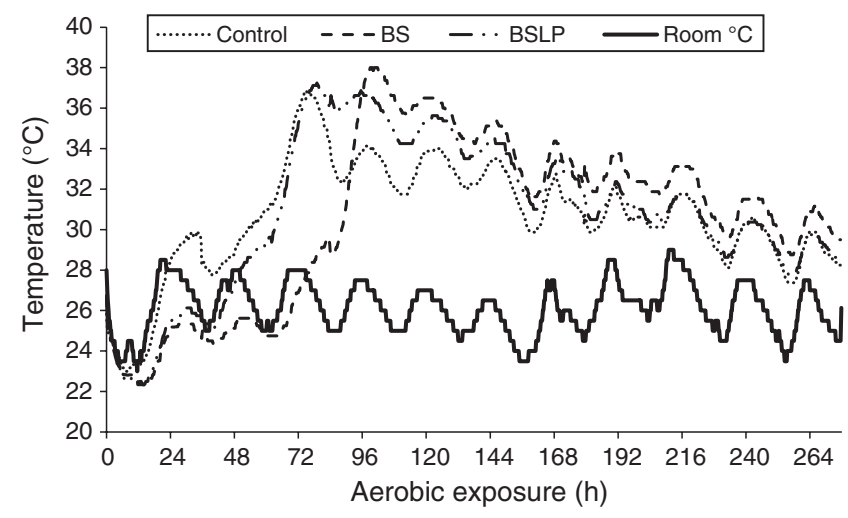

Fig. 4. Changes in the temperature of corn silages inoculated with microbial inoculants during aerobic exposure. Silages: Control $=$ untreated. $\mathrm{BS}=$ Bacillus subtilis at $1 \times 10^{5} \mathrm{cfu} / \mathrm{g}$ of fresh forage. $\mathrm{BSLP}=$ B. subtilis and Lactobacillus plantarum at $1 \times 10^{5} \mathrm{cfu} / \mathrm{g}$ of fresh forage.

the digestibility of OM. In addition, inoculated silages had higher aerobic stability and lower mould and yeast populations, which contributed, along with the reduction of the NDF, to improving the IVDOM. According to the literature, BS can produce bacteriocins and enzymes such as $\alpha$-amylase and ferulate esterase (Donaghy and McKay 1997). The decrease in the NDF content of inoculated silage may be due to the action of ferulate esterase, which breaks ester bonds between lignin and hemicellulose, allowing the enzymes to act upon hemicellulases and cellulases in the fibre matrix. The results shown in Fig. 2 confirm these hypotheses because the NDF content in the silage Control (nearly 15\%) was higher than that in silage treated with inoculants (nearly 13\%). Moreover, it is necessary to consider the action of $\alpha$-amylase produced by BS, as this enzyme can increase the digestibility of starch, thereby increasing digestibility of the inoculated silage.

According to Oba and Allen (1999), increasing the in vitro digestibility of NDF by 1 unit results in a potential increase in DM intake of $0.17 \mathrm{~kg} /$ day and an increase in milk yield of $0.25 \mathrm{~kg} /$ day. Thus, the present study shows that there is a change in the nutritive value of silage inoculated with BS alone or combined with LP. However, the mechanisms responsible for this change are unknown, and the results found in the literature are not consistent. Thus, additional research should be performed to determine whether bacterial inoculants produce ferulate esterases and to validate the effects of bacterial inoculants on intake by animals and their performance.

Corn silage has a residual soluble carbohydrate concentration and a DM concentration of $\sim 30 \%$. These conditions favour the development of moulds and yeasts associated with aerobic stability (Muck et al. 1991). Inoculation with heterofermentative microorganisms has been used to control aerobic stability. These inoculants act by inhibiting opportunistic microorganisms after silo opening, either by the increased production of acetic acid (Danner et al. 2003; Filya 2003a, 2003b) or by the production of bacteriocins (Yildirim and Yildirim 2001).

In the present study, silages inoculated with BS had lower occurrences of yeasts and moulds 1 day and 4 days, respectively, after the opening of the mini-silos, promoting greater aerobic 
stability in this silage. BS is one of the most important producers of metabolites with antifungal and antibacterial activity (Todovora and Kozhuharova 2009). Basso et al. (2012) also found improvements in the aerobic stability of corn silage inoculated with BS.

\section{Conclusions}

Silages inoculated with BS alone or combined with LP preserved the fermentation characteristics, decreased the NDF content and increased the in vitro digestibility of corn silages, improving their nutritive value. BS decreased the populations of yeasts and moulds and increased aerobic stability.

\section{Acknowledgement}

The authors express their appreciation to the Sao Paulo Research Foundation - FAPESP for their financial support.

\section{References}

AOAC (1996) 'Official methods of analysis.' 16th edn. (Association of Official Analytical Chemists: Arlington, VA)

Baah J, Addah W, Okine EK, McAllister TA (2011) Effects of homolactic bacterial inoculant alone or combined with an anionic surfactant on fermentation, aerobic stability and in situ ruminal degradability of barley silage. Asian-Australasian Journal of Animal Sciences 24, 369-378. doi:10.5713/ajas.2011.10320

Barker SB, Summerson WH (1941) The colorimetric determination of lactic acid in biological material. The Journal of Biological Chemistry 138, $535-554$.

Basso FC, Lara EC, Rabelo CHS, Morelli M, Gonçalves GS, Reis RA (2011) Fermentation and aerobic stability of corn silage inoculated with bacterial additives. In 'II international symposium on forage quality and conservation'. Proceedings. (Eds M Zopollato, JLP Daniel, LG Nussio, AS Neto) pp. 48-49. (Fundação de Estudos Agrários Luiz de Queiroz, Piracicaba, São Paulo, Brazil)

Basso FC, Lara EC, Assis FB, Rabelo CHS, Morelli M, Reis RA (2012) 423 Características da fermentação e estabilidade aeróbia de silagens de milho inoculadas com Bacillus subtilis. Revista Brasileira de Saúde e Produção Animal 13, 1009-1019. doi:10.1590/S1519-99402012000 400003

Cherney JH, Cherney DJR (2003) Assessing silage quality. In 'Silage science and technology'. (Eds DR Buxton, RE Muck, JH Harrison) pp. 141-198. (American Society of Agronomy, Crop Science Society of America, Soil Science of America: Madison, WI)

Cone JW, Van Gelder AH, Driehuis F (1997) Description of gas production profiles with a three phasic model. Animal Feed Science and Technology 66, 31-45. doi:10.1016/S0377-8401(96)01147-9

Danner H, Holzer M, Mayrhuber E, Braun R (2003) Acetic acid increases stability of silage under aerobic conditions. Applied and Environmental Microbiology 69, 562-567. doi:10.1128/AEM.69.1.562-567.2003

Donaghy J, McKay AM (1997) Purification and characterization of a feruloyl esterase from the fungus Penicillium expansum. Journal of Applied Microbiology 83(6), 718-726. doi:10.1046/j.1365-2672.1997.00307.x

Filya I (2003a) The effect of Lactobacillus buchneri, with or without homofermentative lactic acid bacteria, on the fermentation, aerobic stability, and ruminal degradability of wheat, sorghum, and maize silages. Journal of Applied Microbiology 95, 1080-1086. doi:10.1046/ j.1365-2672.2003.02081.x

Filya I (2003b) The effect of Lactobacillus buchneri and Lactobacillus plantarum on the fermentation, aerobic stability and ruminal degradability of low dry matter corn and sorghum silages. Journal of Dairy Science 86, 3575-3581. doi:10.3168/jds.S0022-0302(03)73963-0
Jobim CC, Cecato U, Canto MW (2001) Utilização de silagem de grãos de cereais na alimentação animal. In 'Simpósio Sobre Produção e Utilização de Forragens Conservadas'. (Eds CC Jobim, U Cecato, JC Damasceno, GT Santos) pp. 146-176. (Universidade Estadual de Maringá/Centro de Ciências Agrárias/Departamento de Zootecnia: Maringá, Paraná)

Jobim CC, Nussio LG, Reis RA, Schmidt P (2007) Avanços metodológicos na avaliação da qualidade da forragem conservada. Revista Brasileira de Zootecnia 36, 101-119. doi:10.1590/S1516-35982007001000013

Kung L (2009) Effects of microbial additives in silages: facts and perspectives. In 'International symposium on forage quality and conservation'. (Eds M Zopollatto, GB Muraro, LG Nussio) pp. 7-22. (Fundação de Estudos Agrários Luiz de Queiroz: Piracicaba, Sao Paulo, Brazil)

Kung L, Jr, Grieve DB, Thomas JW, Huber JT (1984) Added ammonia or microbial inoculant for fermentation and nitrogenous compounds of alfalfa ensiled at various percents of dry matter. Journal of Dairy Science 67, 299-306. doi:10.3168/jds.S0022-0302(84)81302-8

Kung L, Jr, Taylor CC, Lynch MP, Neylon JM (2003) The effect of treating Alfafa with Lactobacillus Buchneri 40788 on silage fermentation, aerobic stability, and nutritive value for lactating dairy cows. Journal of Dairy Science 86, 336-343. doi:10.3168/jds.S0022-0302(03)73611-X

Lanna Filho R, Ferro HM, Pinho RSC (2010) Controle biológico mediado por Bacillus subtilis. Revista Trópica. Ciências Agrárias e Biológicas 4, 12-20.

Mauricio RM, Mould FL, Dhanoa MS, Owen E, Channa KS, Theodorou MK (1999) A semi-automated in vitro gas production technique for ruminant feedstuff evaluation. Animal Feed Science and Technology 79, 321-330. doi:10.1016/S0377-8401(99)00033-4

McAllister TA, Selinger LB, McMahon LR, Bae HD, Lysyk TJ, Oosting SJ, Cheng KJ (1995) Intake, digestibility and aerobic stability of barley silage inoculated with mixtures of Lactobaciollus plantarum and Enterococcus faecium. Canadian Journal of Animal Science $\mathbf{7 5}$, 425-432. doi:10.4141/cjas95-062

McDonald P, Henderson AR, Heron SJE (1991) 'The biochemistry of silage.' 2nd edn. (Chalcombe Publications: Marlow, Bucks, UK)

Menke KH, Raab L, Salewski A, Steingass H, Fritz D, Schneider W (1979) The estimation of the digestibility and metabolisable energy content of ruminant feeding stuffs from the gas production when they are incubated with rumen liquor in vitro. The Journal of Agricultural Science 93, 217-222. doi:10.1017/S0021859600086305

Mertens DR (2002) Gravimetric determination of amylase treated neutral detergent fiber in feeds with refluxing in beakers or crucibles: collaborative study. Journal of AOAC International 85, 1212-1240.

Muck RE (1996) Silage inoculation: inoculation of silage and its effects on silage quality. In 'Conference with dairy and forage industries'. Proceedings. pp. 43-51. (Dairy Forage Research Center: Madison, WI)

Muck RE (2004) Effects of corn silage inoculants on aerobic stability. Transactions of the ASAE. American Society of Agricultural Engineers 47, 1011-1016. doi:10.13031/2013.16571

Muck RE, Pitt RE, Leibensperger RY (1991) A model of aerobic fungal growth in silage. Microbial characteristics. Grass and Forage Science 46, 283-299. doi:10.1111/j.1365-2494.1991.tb02234.x

Oba M, Allen MS (1999) Evaluation of the importance of digestibility of NDF from forage: effects on dry matter intake and milk yield of dairy cows. Journal of Dairy Science 82, 589-596. doi:10.3168/jds.S00220302(99)75271-9

Pahlow G, Muck RE, Driehuis F, Oude Elferink SJWH, Spoelstra SF (2003) Microbiology of ensiling. In 'Silage science and technology'. (Eds DR Buxton, RE Muck, JH Harrison) pp. 31-94. (American Society of Agronomy: Madison, WI)

Phillip LE, Fellner V (1992) Effects of bacterial inoculation of high-moisture ear corn on its aerobic stability, digestion, and utilization for growth by beef steers. Journal of Animal Science 70, 3178-3187. 
Senger CCD, Kozloski GV, Sanchez LMB, Mesquita FR, Alves TP, Castagnino DS (2008) Evaluation of autoclave procedures for fibre analysis in forage and concentrate feedstuffs. Animal Feed Science and Technology 146, 169-174. doi:10.1016/j.anifeedsci.2007.12.008

Todovora S, Kozhuharova L (2009) Characteristics and antimicrobial activity of Bacillus subtilis strains isolated from soil. Journal of Microbiology and Biotechnology 96, 1151-1161.

Weinberg ZG, Muck RE (1996) New trends in development and use of inoculants for silage. FEMS Microbiology Reviews 19, 53-68. doi:10.1111/j.1574-6976.1996.tb00253.x
Yildirim Z, Yildirim M (2001) Caracterization of buchnericin LB produced by Lactobacillus buchneri LB. Turkish Journal of Biology 25, 73-82.

Zahiroddini H, Baah J, Absalom W, McAlister TT (2004) Effect of an inoculant and hydrolytic enzymes on fermentation and nutritive value of whole crop barley silage. Animal Feed Science and Technology 117, 317-330. doi:10.1016/j.anifeedsci.2004.08.013 